\section{Market Quality of Guavas after Hot-water Quarantine Treatment and Application of Carnauba Wax Coating}

\author{
Raymond G. McGuire \\ U.S. Department of Agriculture, Agricultural Research Service, Subtropical \\ Horticulture Research Station, 13601 Old Cutler Road, Miami, FL 33158
}

Additional index words. Psidium guajava, Anastrepha suspensa, modified atmosphere storage

\begin{abstract}
Immersion of guavas (Psidium guajava L.) for 35 min in water at $46.1 \pm 0.2{ }^{\circ} \mathrm{C}$ slowed softening, sweetening, and color development of fruit and delayed ripening by 2 days. Heat treatment also increased susceptibility to chilling injury, decay, and weight loss in storage, but overall loss of quality was minimal. Waxing fruit within 90 min of heat treatment exacerbated chilling injury, further delayed ripening with a concomitant increase in the percentage of fruit not ripening, and caused fruit to remain greener. Waxed fruit had a lower acidity and soluble solids concentration and did not appear to ripen normally. Although heating did not appreciably affect the percentage of fruit that failed to ripen, the combination of heating and nearly immediate waxing increased the proportion not ripening to $45 \%$. Heat and wax treatments, alone or in combination, caused $\mathrm{CO}_{2}$ levels to increase significantly before the initiation of ripening, but waxing also reduced the $\mathrm{O}_{2}$ content of fruit at this time. Before ripening, $\mathrm{O}_{2}$ levels were inversely correlated $(r \leq-$ 0.950 ) with injury, firmness, date and percentage of fruit ripening, and $\mathrm{pH}$ and directly correlated $(r \geq 0.950)$ with peel color and the concentration of acids and sugars in the pulp. Delaying the waxing of heat-treated guavas or reconditioning them for $24 \mathrm{~h}$ at $20^{\circ} \mathrm{C}$ before cold storage promoted normal ripening and helped to maintain the quality of heat-treated fruit.
\end{abstract}

Guava fruit are preferred by female Caribbean fruit flies [Anastrepha suspensa (Loew.)] for oviposition, and virtually all guavas from South Florida contain larvae of these insects (Murray and Campbell, 1989). With no flyfree zones in the commercial growing areas, all fruit to be exported to states and countries with an environment conducive to fly development must be treated to eradicate this pest. A quarantine protocol has been proposed by Gould and Sharp (1992) that employs a 35min immersion in water at $46.1 \pm 0.5^{\circ} \mathrm{C}$.

Guavas are climacteric with high rates of respiration and usually ripen within 7 days at $20{ }^{\circ} \mathrm{C}$ (Campbell, 1994). Waxing has generally not been included in the postharvest processing of this commodity. Markets that have gradually expanded outside Florida, however, require increased transit times in many cases, and waxing fruits is a common method to decrease moisture loss in storage and transit (Kester and Fennema, 1986). Depending on their composition and thickness, all fruit coatings resist the exchange of gases and affect the rate of fruit ripening (Smith et al., 1987). The application of a cellulose-based film to papa-

Received for publication 22 Apr. 1996. Accepted for publication 22 Oct. 1996. I thank Everton Bather for his technical assistance and Maria Trunk of Brooks Tropicals, Inc., which provided the fruit used in these experiments. Mention of a trade name does not constitute a recommendation by the U.S Dept. of Agriculture. The cost of publishing this paper was defrayed in part by the payment of page charges. Under postal regulations, this paper therefore must be hereby marked advertisement solely to indicate this fact.

HortScience, Vol. 32(2), AprIL 1997 fruit for $24 \mathrm{~h}$ at $20^{\circ} \mathrm{C}$ before 7 days of storage at $12^{\circ} \mathrm{C}$ and of delaying waxing until removal to $20^{\circ} \mathrm{C}$ were compared, again in a split-plot design. The combination treatment in the first test was appropriated as the control in the second test. After 7 days of storage at $12^{\circ} \mathrm{C}$, all fruit were removed to $20{ }^{\circ} \mathrm{C}$ to ripen. Each treatment of both tests consisted of 20 fruit that were initially and individually weighed. The treatment procedure was replicated a total of six times throughout the season.

After their transfer from 12 to $20^{\circ} \mathrm{C}$ for ripening, fruit were examined daily, and the day was noted when gentle finger pressure applied from both sides simultaneously could indent the fruit $\approx 0.5 \mathrm{~cm}$. This subjective measure of firmness corresponded to a resistance by the fruit of 13 to $23 \mathrm{~N}$; at harvest, resistance averaged $95 \mathrm{~N}$. As fruit softened and were subjectively estimated to be ripe, their quality was evaluated. Fruit were weighed a second time. They were then rated for the percentage of surface decay and for surface blackening caused by chilling injury $(\mathrm{CI})$ with a 12-point visual acuity scale (Horsfall and Barratt, 1945). Firmness of each fruit was measured with an Instron Universal Testing Instrument (model 1011; Instron Corp., Canton, Mass.) fitted with a compression anvil of $12 \mathrm{~mm}$ diameter; resistance to pressure was recorded after a compression of $3 \mathrm{~mm}$. Peel color was evaluated with a Minolta CR-200 Chroma-meter (Minolta Corp., Ramsey, N.J.) calibrated with a standard white reflective plate and recording in the tristimulus $L^{*} C^{*} h^{\circ}$ system (lightness where 100 is white and 0 is black, chroma where 100 is most intense and 0 is least intense, and hue angle where $0^{\circ}$ is red-purple, $90^{\circ}$ is yellow, $180^{\circ}$ is bluish green, and $270^{\circ}$ is blue, respectively); measurements were taken across an area $\approx 50 \mathrm{~mm}^{2}$ with diffuse illumination at a viewing angle of $0^{\circ}$ under CIE illuminant $C$ conditions (McGuire, 1992).

Ten ripe fruit were selected per treatment for an analysis of the pulp. Individual fruit were peeled, and $\approx 25 \mathrm{~g}$ of pulp was forced through a sieve with holes $\approx 1 \mathrm{~mm}^{2}$ (16 mesh) to remove seeds. The $\mathrm{pH}$ of the pulp was measured, and $1.5 \mathrm{~g}$ was transferred to a centrifuge tube and spun at $5000 \times \mathrm{g}$ for $15 \mathrm{~min}$; a refractive index was determined on the supernatant for calculation of the total percentage of soluble solids (SSC). Twenty grams of pulp was titrated with $0.1 \mathrm{M} \mathrm{NaOH}$ to determine the total percentage of acids.

Within each test, the data were compared using PROC analysis of variance (ANOVA) in SAS (1985). One split-plot analysis compared the co-effects of heat and wax; a second split-plot analysis, on heated fruit only, compared reconditioning and time of wax application. Horsfall/Barratt rating values, after analysis, were converted to percent surface area decayed or percent surface area injured.

Measurement of internal gases. Internal concentrations of $\mathrm{O}_{2}$ and $\mathrm{CO}_{2}$ were measured from guavas treated as above and stored at 12 ${ }^{\circ} \mathrm{C}$ for 1 week before ripening at $20^{\circ} \mathrm{C}$. Concentrations in comparably treated fruit not temporarily cold-stored were examined for comparison. Before waxing, if required, but 
after any prescribed heating, a sleeve-type rubber stopper was attached to the surface of each fruit. The sleeve portion of the stopper was affixed to the fruit surface with silicone rubber sealant to form an airtight cylindrical chamber $15 \mathrm{~mm}$ in diameter $\times 15 \mathrm{~mm}$ in height $(2.65 \mathrm{~mL})$. Although fruit may have been subsequently coated, the area within the chamber was free of any film, and gas exchange through the stomates was presumed to be unhampered and the sample representative of concentrations beneath the fruit peel. Beginning the day after treatment and continuing daily for 3 weeks, $1 \mathrm{~mL}$ of gas was withdrawn from the chamber by inserting an 18-gauge $(\approx 0.1 \mathrm{~mm}$ bore diameter) needle through the stopper. This gas was then injected through a port into an SRI 8610 gas chromatograph (SRI Instruments, Torrance, Calif.) equipped with a CTR I column (Alltech Assoc., Deerfield, Ill.) with helium as the carrier gas. Areas under the peaks were summed, and, based upon retention times, concentrations of $\mathrm{O}_{2}$ and $\mathrm{CO}_{2}$ were determined as percentages of this sum. Three fruit were averaged per treatment. The treatment procedure was replicated a total of three times (separate from quality trials) over 3 months.

With each treatment, the $\mathrm{CO}_{2}$ level increased after 2 or 7 days, dependent on initial storage temperature, which indicated the initiation of ripening. Based upon the times of these increases, results were classified as occurring before or after ripening had begun. Within these two periods, average gas concentrations were analyzed by PROC ANOVA in SAS comparing the effects of storage at $12^{\circ} \mathrm{C}$, heating, and waxing or the effects of reconditioning and time of wax application on heated, waxed fruit. Concentrations of $\mathrm{O}_{2}$ and $\mathrm{CO}_{2}$ before and after the initiation of ripening were correlated (PROC CORR in SAS) with quality attributes.

\section{Results}

Quality evaluation. Hot-water treatment significantly affected $(P \leq 0.05)$ every quality attribute except firmness and external color of ripe fruit and the $\mathrm{pH}$ of the ripe guava pulp (Table 1). Since finger pressure determined when quality was evaluated, measurements of firmness were generally within the range of 13 to $23 \mathrm{~N}$ for each treatment at the time of evaluation. Significant differences in the number of days required by fruit to ripen, however, suggest that firmness, too, would be different for heated and nonheated fruit on any particular day. Regardless of whether or not fruit were waxed, hot-water treatment delayed ripening by $\approx 2$ days and increased the percentage of fruit that did not ripen. Heat treatment also increased the subsequent severity of CI due to storage at $12{ }^{\circ} \mathrm{C}$ and of decay expressed at 20 ${ }^{\circ} \mathrm{C}$, increased weight loss, and reduced the percentage of acids and SSC within the pulp.

Waxing fruit within 90 min of heat treatment significantly influenced every quality character except surface decay and weight loss (Table 1). Regardless of whether or not fruit were heated, waxed fruit remained firmer,

Table 1. Quality of guavas as affected by hot-water treatment $\left(35 \mathrm{~min}\right.$ at $\left.46.1 \pm 0.2^{\circ} \mathrm{C}\right)$ and application of carnauba wax.

\begin{tabular}{|c|c|c|c|c|c|c|c|}
\hline \multirow{3}{*}{$\begin{array}{l}\text { Quality } \\
\text { of ripe fruit }\end{array}$} & & & & \multicolumn{4}{|c|}{ Storage at $12^{\circ} \mathrm{C}$ for 7 days, $20^{\circ} \mathrm{C}$ to ripen } \\
\hline & \multicolumn{3}{|c|}{ Statistics $^{\mathrm{z}}$} & \multicolumn{2}{|c|}{$\begin{array}{c}\text { No hot-water } \\
\text { treatment }\end{array}$} & \multicolumn{2}{|c|}{$\begin{array}{c}\text { Hot-water } \\
\text { treated }\end{array}$} \\
\hline & Heat & Wax & $\mathrm{H} \times \mathrm{W}$ & No wax & Wax & No wax & Wax \\
\hline Firmness (N) & NS & $* *$ & NS & 14.0 & 22.2 & 14.4 & 22.6 \\
\hline \multicolumn{8}{|l|}{ Time to ripen } \\
\hline at $20^{\circ} \mathrm{C}$ (days) & * & $* *$ & NS & 5.0 & 7.8 & 7.1 & 10.5 \\
\hline Not ripening (\%) & * & $* * *$ & $*$ & 0.0 & 16.6 & 1.6 & 44.9 \\
\hline Surface injury (\%) & $* *$ & $* *$ & NS & 1.7 & 22.4 & 10.6 & 28.7 \\
\hline Surface decay $(\%)$ & $* * *$ & NS & $*$ & 9.2 & 8.7 & 14.7 & 17.3 \\
\hline Weight loss (\%) & $* *$ & NS & NS & 9.2 & 10.0 & 13.3 & 12.7 \\
\hline Color darkness $\left(L^{*}\right)$ & NS & ** & NS & 60.8 & 53.0 & 58.1 & 52.2 \\
\hline Intensity $\left(\mathrm{C}^{*}\right)$ & NS & $* * *$ & NS & 41.0 & 32.8 & 40.7 & 32.5 \\
\hline Hue $\left(h^{\circ}\right)$ & \# & $* *$ & NS & 91.9 & 99.6 & 88.1 & 97.8 \\
\hline Pulp pH & NS & $* *$ & $\#$ & 4.04 & 4.14 & 4.01 & 4.26 \\
\hline Total acids (\%) & * & $* * *$ & \# & 0.76 & 0.70 & 0.75 & 0.64 \\
\hline Soluble solids (\%) & * & $* *$ & \# & 9.01 & 8.16 & 8.83 & 7.03 \\
\hline
\end{tabular}

${ }^{\mathrm{x}}$ From analysis of variance: $\mathrm{H} \times \mathrm{W}=$ interaction of heat and wax effects.

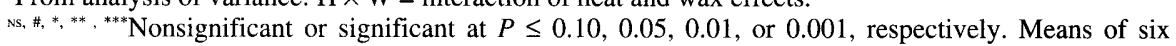
replications.

Table 2. Quality of hot-water-treated $\left(35 \mathrm{~min}\right.$ at $46.1 \pm 0.2^{\circ} \mathrm{C}$ ), waxed guavas as affected by reconditioning at $20^{\circ} \mathrm{C}$ for $24 \mathrm{~h}$ before storage at $12{ }^{\circ} \mathrm{C}$ and application of carnauba wax before or after storage at 12 ${ }^{\circ} \mathrm{C}$.

\begin{tabular}{|c|c|c|c|c|c|c|c|}
\hline \multirow[b]{3}{*}{$\begin{array}{l}\text { Quality } \\
\text { of ripe fruit }\end{array}$} & \multirow{2}{*}{\multicolumn{3}{|c|}{ Statistics $^{z}$}} & \multicolumn{4}{|c|}{ Storage at $12^{\circ} \mathrm{C}$ for 7 days, $20^{\circ} \mathrm{C}$ to ripen } \\
\hline & & & & \multicolumn{2}{|c|}{ No reconditioning } & \multicolumn{2}{|c|}{ Reconditioning } \\
\hline & $\begin{array}{l}\text { Recon- } \\
\text { dition }\end{array}$ & $\begin{array}{l}\text { Wax } \\
\text { time }\end{array}$ & $\mathrm{R} \times \mathrm{T}$ & $\begin{array}{c}\text { Wax } \\
\text { Pre } 12^{\circ} \mathrm{C}\end{array}$ & $\begin{array}{c}\text { Wax } \\
\text { Post } 12^{\circ} \mathrm{C}\end{array}$ & $\begin{array}{c}\text { Wax } \\
\text { Pre } 12^{\circ} \mathrm{C}\end{array}$ & $\begin{array}{c}\text { Wax } \\
\text { Post } 12^{\circ} \mathrm{C}\end{array}$ \\
\hline Firmness (N) & $*$ & $* * *$ & NS & 22.6 & 17.6 & 20.1 & 15.6 \\
\hline Time to ripen & NS & * & NS & 105 & 75 & 84 & 65 \\
\hline Not ripening $(\%)$ & ** & ** & NS & 44.9 & 17.4 & 26.7 & 3.7 \\
\hline Surface injury (\%) & NS & * & NS & 28.7 & 15.4 & 25.2 & 13.9 \\
\hline Surface decay (\%) & * & ** & NS & 17.3 & 7.8 & 11.9 & 4.1 \\
\hline Weight loss $(\%)$ & NS & * & NS & 12.7 & 10.8 & 12.5 & 10.8 \\
\hline Color darkness ( $\left.\mathrm{L}^{*}\right)$ & NS & $*$ & NS & 52.2 & 54.1 & 52.9 & 54.4 \\
\hline Intensity $\left(C^{*}\right)$ & NS & \# & NS & 32.5 & 34.7 & 33.3 & 34.7 \\
\hline Hue $\left(h^{\circ}\right)$ & NS & NS & NS & 97.8 & 100.1 & 98.9 & 98.6 \\
\hline Pulp pH & \# & $*$ & NS & 4.26 & 4.10 & 4.18 & 3.95 \\
\hline Total acids (\%) & \# & * & NS & 0.64 & 0.73 & 0.71 & 0.75 \\
\hline Soluble solids (\%) & NS & ** & NS & 7.03 & 8.28 & 7.54 & 8.13 \\
\hline
\end{tabular}

${ }^{2}$ From analysis of variance: $\mathrm{R} \times \mathrm{T}=$ interaction of reconditioning and waxing time effects.

ws, $\#, *,{ }^{* *},{ }^{* * *}$ Nonsignificant or significant at $P \leq 0.10,0.05,0.01$, or 0.001 , respectively. Means of six replications.

ripening was delayed by $\approx 3$ days with a concomitant increase in the percentage of fruit not ripening, and $\mathrm{CI}$ at $12{ }^{\circ} \mathrm{C}$ was significantly exacerbated. Waxed fruit remained darker with a less intense, greener hue. Regardless of heat treatment, waxed fruit had a lower acidity and SSC and generally did not appear to ripen normally. Although heating alone did not appreciably affect the percentage of fruit that failed to ripen, which was $<2 \%$, the combination of heating and nearly immediate waxing increased the proportion not ripening to $45 \%$.

Reconditioning fruit at $20{ }^{\circ} \mathrm{C}$ for $24 \mathrm{~h}$ immediately after heat treatment significantly affected $(P \leq 0.05)$ firmness, the percentage of fruit that did not ripen, decay, and (at $P \leq 0.10$ ) pulp characteristics (Table 2). Regardless of when wax was applied, the reconditioning of heat-treated fruit allowed fruit to soften more normally, although the time required to ripen could not be statistically differentiated. The percentage of fruit that did not ripen was significantly lower with reconditioning, decay was reduced, and the pulp of ripe fruit had a higher percentage of acids with a concomitantly lower $\mathrm{pH}$.
Delaying the waxing of fruit until storage at $12^{\circ} \mathrm{C}$ was complete significantly $(P \leq 0.05)$ improved all quality characteristics, except peel color (Table 2). Although fruit coated after $12{ }^{\circ} \mathrm{C}$ storage were not as dark, and color intensity was somewhat greater, their greenish hue remained unchanged. Regardless of reconditioning, delaying the wax application to heated fruit allowed them to soften and ripen more quickly and reduced the percentage of fruit that failed to ripen. The surface development of CI and decay in the subsequent storage periods was reduced, as was weight loss since fewer days were required to ripen at $20^{\circ} \mathrm{C}$. Delayed waxing also significantly increased the percentage of acids in the pulp with a concomitant reduction in $\mathrm{pH}$ and the SSC. Combining the delayed waxing of fruit with reconditioning appeared numerically to offer some advantages for quality maintenance, but the benefits were not statistically significant.

Internal gases. Nontreated fruit harvested and allowed to ripen immediately at $20^{\circ} \mathrm{C}$ (no $12{ }^{\circ} \mathrm{C}$ storage) developed internal levels of $\mathrm{CO}_{2}$ that rose from $\approx 1 \%$ to $6 \%$ by day 10 when fruit were ripe (Fig. 1A). Oxygen was at its 

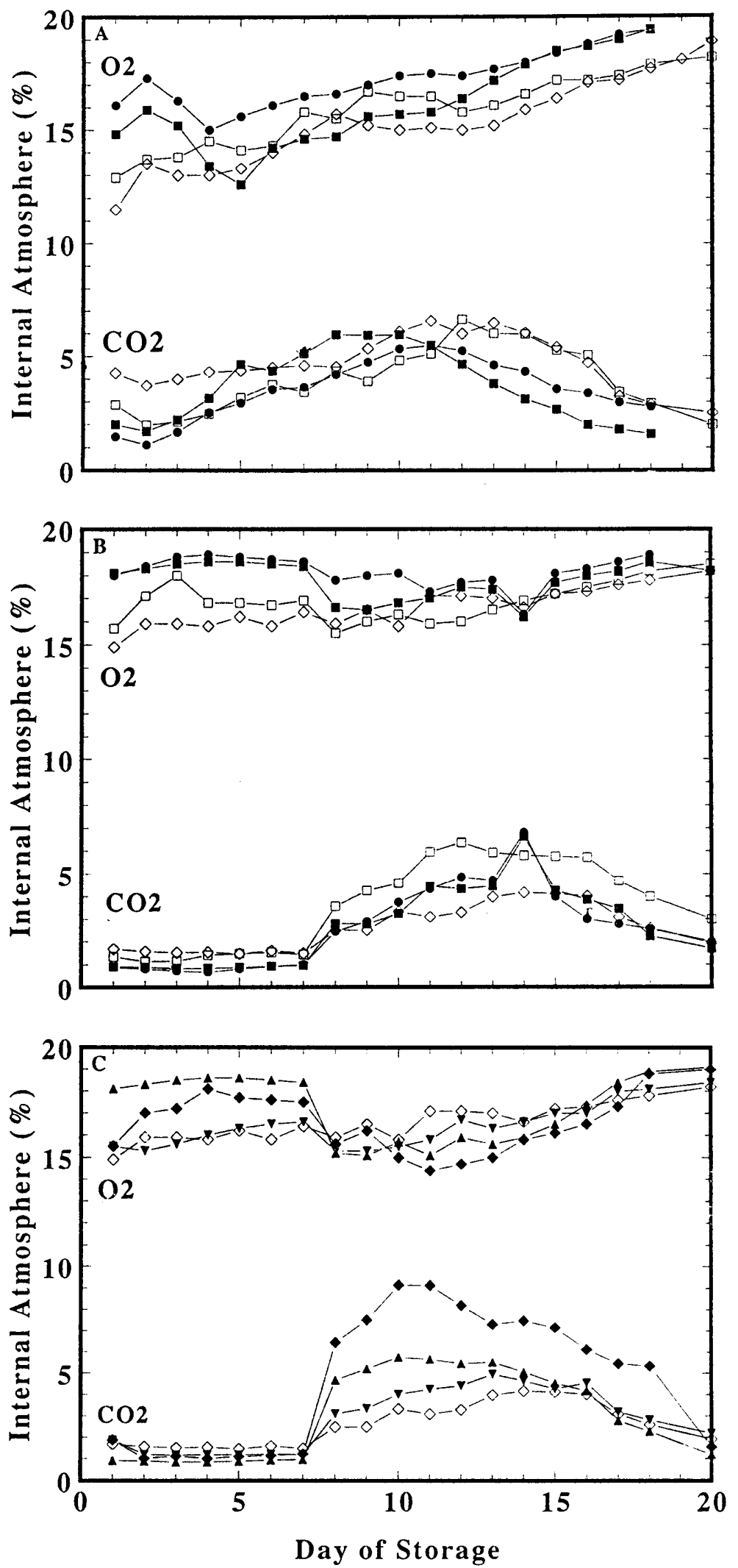

Fig. 1. Concentrations of $\mathrm{O}_{2}$ and $\mathrm{CO}_{2}$ within guavas during postharvest storage and ripening. A) Fruit ripened at $20^{\circ} \mathrm{C}$; B and C) fruit stored at $12^{\circ} \mathrm{C}$ for 7 days then ripened at $20^{\circ} \mathrm{C}$. Fruit in A and B: (O) neither

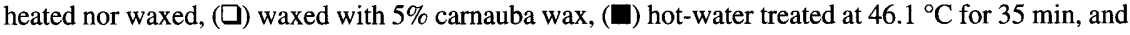
$(\diamond)$ waxed $90 \mathrm{~min}$ after hot water treatment. Fruit in $C$ were all heated then: $(\diamond)$ waxed $90 \mathrm{~min}$ after hot water treatment immediately before storage at $12{ }^{\circ} \mathrm{C},(\Delta)$ waxing delayed until storage at $12{ }^{\circ} \mathrm{C}$ was complete, $(\nabla)$ reconditioned for $24 \mathrm{~h}$ at $20^{\circ} \mathrm{C}$ before waxing and storage at $12^{\circ} \mathrm{C}$, and $(\bullet)$ reconditioned with delayed waxing. Means of three replications. Treatments in Figs. 1B and 1C correspond to those in Tables 1 and 2, respectively; treatments in Fig. 1A have no tabular counterpart. lowest concentration of $15 \%$ soon after ripening began, then rose consistently. The remaining $77 \%$ to $81 \%$ of the atmosphere within the fruit was $\mathrm{N}_{2}$ (not shown). Compared with untreated fruit, hot-water treatment advanced ripening by 2 days; during the ripening period $\mathrm{O}_{2}$ remained lower and $\mathrm{CO}_{2}$ higher than was measured in nonheated fruit. Waxing fruit, with or without heating, initially reduced the $\mathrm{O}_{2}$ level to $11 \%$ to $13 \%$ and doubled the amount of $\mathrm{CO}_{2}$ recovered, which eventually peaked at $6.5 \%$. Waxed guavas did not ripen until several days after this $\mathrm{CO}_{2}$ peak, on days 16 and 17 , respectively, whereas unwaxed fruit were ripe at the times $\mathrm{CO}_{2}$ peaked.

During storage at $12{ }^{\circ} \mathrm{C}$, unwaxed guavas maintained levels of $\mathrm{O}_{2}$ and $\mathrm{CO}_{2}>18 \%$ and $<1 \%$, respectively (Fig. 1B). During this period, waxed fruit generally contained $15 \%$ to $17 \% \mathrm{O}_{2}$ and $1 \%$ to $2 \% \mathrm{CO}_{2}$. After removal to $20{ }^{\circ} \mathrm{C}$ on the 7 th day of storage, ripening accelerated in all fruit as indicated by a sharp rise in $\mathrm{CO}_{2}$. The ripening period was condensed compared with that of fruit not initially stored at $12^{\circ} \mathrm{C}$. Storage at $12^{\circ} \mathrm{C}$ allowed $\mathrm{O}_{2}$ to rise significantly in fruit before their removal to $20^{\circ} \mathrm{C}$, with a concomitant reduction in the percentage of $\mathrm{CO}_{2}$ (Table 3 ). Fruit previously stored at $12{ }^{\circ} \mathrm{C}$ contained significantly more $\mathrm{O}_{2}$ during ripening as well.

Regardless of storage at $12{ }^{\circ} \mathrm{C}$, waxing significantly reduced $\mathrm{O}_{2}$ within fruit before ripening was initiated, and, at this time, both heating and waxing fruit caused $\mathrm{CO}_{2}$ to rise significantly with a significant interaction between the effects. Neither heating nor waxing significantly affected atmospheric gases within fruit during ripening, however (Table 3). Before ripening, the levels of $\mathrm{O}_{2}$ and $\mathrm{CO}_{2}$ in fruit stored at $12{ }^{\circ} \mathrm{C}$ were highly correlated $(r=$ $-0.992)$; this relationship was lost, however, as fruit ripened $(r=-0.581)$. Oxygen levels before ripening were inversely correlated $(r \leq$ -0.950 ) with injury, firmness, date of ripening, the percentage of fruit not ripening, and $\mathrm{pH}$ and directly correlated $(r \geq 0.950)$ with the darkness $\left(\mathrm{L}^{*}\right)$ and chroma $\left(\mathrm{C}^{*}\right)$ of peel color and the concentration of acids and sugars in the pulp.

Delaying the waxing of heat-treated guavas until their removal from storage at $12^{\circ} \mathrm{C}$ allowed $\mathrm{O}_{2}$ levels to remain elevated until ripening was initiated at $20{ }^{\circ} \mathrm{C}$ (Fig. 1C). Delayed waxing and reconditioning fruit for $24 \mathrm{~h}$ at $20^{\circ} \mathrm{C}$ before cold storage, and the interaction of these effects, significantly affected the level of $\mathrm{CO}_{2}$ in these heated fruit during ripening (Table 3 ). Both effects caused $\mathrm{CO}_{2}$ to rise, peaking as high as $9.5 \%$ with concomitant reductions in $\mathrm{O}_{2}$ (Fig. 1C). As was previously the case, waxed fruit did not ripen until several days after $\mathrm{CO}_{2}$ peaked. Within this test, in which all fruit were heated and waxed, $\mathrm{O}_{2}$ and $\mathrm{CO}_{2}$ before and after ripening was initiated were correlated at -0.937 and -0.985 , respectively. Although the SSC of ripe fruit was correlated $(r=0.942)$ with $\mathrm{O}_{2}$ before ripening, other significant relationships with decay, firmness, the number of fruit not ripening, and $\mathrm{pH}$ were related to $\mathrm{O}_{2}$ levels after ripening was initiated $(r \geq 0.950)$. Less signifi- 
Table 3. Effects of storage at $12{ }^{\circ} \mathrm{C}$, hot water treatment $\left(35 \mathrm{~min}\right.$ at $46.1 \pm 0.2^{\circ} \mathrm{C}$ ), and waxing on $\mathrm{O}_{2}$ and $\mathrm{CO}_{2}$ concentrations in guavas before and after initiation of ripening.

\begin{tabular}{|c|c|c|c|c|c|c|c|c|c|}
\hline & & \multicolumn{8}{|c|}{ Internal atmosphere $(\%)$} \\
\hline & & \multicolumn{4}{|c|}{ Before ripening initiated } & \multicolumn{4}{|c|}{ After ripening initiated } \\
\hline \multicolumn{2}{|l|}{ Variable $^{\mathrm{z}}$} & \multicolumn{2}{|c|}{$\mathrm{O}_{2}$} & \multicolumn{2}{|c|}{$\mathrm{CO}_{2}$} & \multicolumn{2}{|r|}{$\mathrm{O}_{2}$} & \multicolumn{2}{|c|}{$\mathrm{CO}_{2}$} \\
\hline \multirow[t]{2}{*}{$12^{\circ} \mathrm{C}$ storage } & + & $* * *$ & 17.42 & $*$ & 1.16 & $* *$ & 17.03 & NS & 4.03 \\
\hline & - & & 14.51 & & 2.27 & & 15.32 & & 4.35 \\
\hline \multirow[t]{2}{*}{ Heat } & + & NS & 15.58 & $*$ & 2.05 & NS & 15.76 & NS & 4.15 \\
\hline & - & & 16.38 & & 1.38 & & 16.53 & & 4.23 \\
\hline \multirow[t]{2}{*}{ Wax } & + & $* *$ & 14.61 & $* *$ & 2.23 & NS & 15.98 & NS & 4.56 \\
\hline & - & & 17.30 & & 1.19 & & 16.32 & & 3.82 \\
\hline Heat $\times$ wax & & NS & & $*$ & & NS & & NS & \\
\hline \multirow{2}{*}{$\begin{array}{l}\text { Delayed } \\
\text { waxingy }\end{array}$} & + & NS & 17.83 & NS & 1.05 & NS & 15.74 & $* *$ & 6.29 \\
\hline & - & & 15.91 & & 1.42 & & 16.60 & & 3.76 \\
\hline \multirow{2}{*}{$\begin{array}{l}\text { Recondi- } \\
\text { tioning }\end{array}$} & + & NS & 16.61 & NS & 1.25 & NS & 15.90 & ** & 5.88 \\
\hline & - & & 17.14 & & 1.22 & & 16.44 & & 4.17 \\
\hline \multicolumn{10}{|l|}{ Delay $\times$} \\
\hline Recon..$^{y}$ & & NS & & NS & & NS & & $*$ & \\
\hline
\end{tabular}

${ }^{\mathrm{z}}+$ or - signifies means with or without the effect, respectively.

${ }^{\mathrm{y}}$ Treatment on heated and waxed fruit.

Ns, ${ }^{* * *},{ }^{* * *}$ Nonsignificant or significant at $P \leq 0.05,0.01$, or 0.001 , respectively. Means of three replications.

cant $(0.950 \geq r \geq 0.900)$ were relationships between $\mathrm{O}_{2}$ and $\mathrm{CI}$ and date of ripening.

\section{Discussion}

Guavas bound for California, Japan, or other markets where the Caribbean fruit fly could become established need to be treated to kill $99.9968 \%$ of the flies infesting fruit (Gould and Sharp, 1992). Immersion for $35 \mathrm{~min}$ in water at $46.1 \pm 0.2{ }^{\circ} \mathrm{C}$ slowed the softening, sweetening based on SSC, and color development of fruit and delayed ripening by 2 days. Heat treatment also increased susceptibility to chilling injury, decay, and weight loss in storage, but overall loss of quality was minimal.

Waxing, however, significantly reduced the percentage of $\mathrm{O}_{2}$ within guavas, which was correlated with several quality factors. Quality of minimally treated fruit (those heated or waxed, but not both) appeared to be determined by $\mathrm{O}_{2}$ levels before ripening begins. A period of storage at $12{ }^{\circ} \mathrm{C}$ allowed $\mathrm{O}_{2}$ levels to rise within these fruit and tended to counteract some of the ripening delay associated with waxing. Prestorage at $12^{\circ} \mathrm{C}$ reduced the variability in ripening at $20^{\circ} \mathrm{C}$ within a group of fruit and compressed the period of ripening, indicating that some aspects of this process still occurred at $12^{\circ} \mathrm{C}$.

Waxing guavas within a few hours of hotwater treatment was particularly damaging. Oxygen remained low in waxed fruit during storage and levels of $\mathrm{CO}_{2}$ failed to develop normally, indicating an interference with ripening. Reconditioning fruit for $24 \mathrm{~h}$ at $20^{\circ} \mathrm{C}$ after hot-water treatment allowed some recovery from heat damage before the application of wax, but the benefits were slight. Of greater importance was delaying the waxing of fruit until their removal to $20^{\circ} \mathrm{C}$; with fruit better oxygenated, a great deal of recovery could occur during cold storage. Such a delay might be difficult to accommodate in a packing operation, and it negates some of the shelf-life enhancement offered by fruit coatings (Baldwin, 1994). An alternative would be application of a coating more permeable to $\mathrm{O}_{2}$ than carnauba wax.

The ability of coatings to restrict $\mathrm{O}_{2}$ may suggest, however, their usefulness, either alone or in combination with other treatments, in quarantine control of insect pests. Heat and cold treatments may not need to be as severe when coatings are subsequently applied
(Hallman et al., 1994). The development of a more gentle treatment protocol that includes a coating procedure could potentially benefit the export and shelf-life of many delicate tropical fruits.

\section{Literature Cited}

Baldwin, E.A. 1994. Edible coatings for fresh fruits and vegetables: Past, present, and future, p. 2564. In: J.M. Krochta, E.A. Baldwin, and M.O. Nisperos-Carriedo (eds.). Edible coatings and films to improve food quality. Technomic Publ. Co., Lancaster, $\mathrm{Pa}$.

Baldwin, E., M.Nisperos-Carriedo, and C.Campbell. 1992. Extending storage life of papaya with edible coating. HortScience 27:679. (Abstr.)

Campbell, C.A. 1994. Handling of Florida-grown and imported tropical fruits and vegetables. HortScience 29:975-978.

Gould, W.P. and J.L. Sharp. 1992. Hot-water immersion quarantine treatment for guavas infested with Caribbean fruit fly (Diptera: Tephritidae). J. Econ. Entomol. 85:1235-1239.

Hallman, G.J., R.G. McGuire, E.A. Baldwin, and C.A. Campbell. 1995. Mortality of feral Caribbean fruit fly (Diptera: Tephritidae) immatures in coated guavas. J. Econ. Entomol. 88:13531355.

Hallman, G.J., M.O. Nisperos-Carriedo, E.A. Baldwin, and C.A. Campbell. 1994. Mortality of Caribbean fruit fly (Diptera: Tephritidae) immatures in coated fruits. J. Econ. Entomol. 87:752-757.

Horsfall, J.G. and R.W. Barratt. 1945. An improved grading system for measuring plant disease. Phytopathology 35:655. (Abstr.)

Kester, J.J. and O.R. Fennema. 1986. Edible films and coatings: A review. Food Technol. 40:4759.

McGuire, R.G. and G.J. Hallman. 1995. Coating guavas with cellulose- or carnauba-based emulsions retards postharvest ripening. HortScience 30:294-295.

Murray, M.J. and C.A. Campbell. 1989. Guava and passionfruit as commercial crops in Florida. Proc. Fla. State Hort. Soc. 102:212-213.

SAS Institute. 1985. SAS user's guide: Statistics. version 5 (ed.). SAS Inst., Cary, N.C.

Smith, S., J. Geeson, and J. Stow. 1987. Production of modified atmospheres in deciduous fruits by the use of films and coatings. HortScience 22:772-776. 